\title{
Feeding and Distribution of Porosity in Cast Al-Si Alloys as Function of Alloy Composition and Modification
}

Tiedje, Niels Skat; Taylor, John A.; Easton, Mark A.

Published in:

Metallurgical and Materials Transactions A: Physical Metallurgy and Materials Science

Link to article, DOI:

$10.1007 / \mathrm{s} 11661-012-1308-0$

Publication date:

2012

Document Version

Publisher's PDF, also known as Version of record

Link back to DTU Orbit

Citation $(A P A)$ :

Tiedje, N. S., Taylor, J. A., \& Easton, M. A. (2012). Feeding and Distribution of Porosity in Cast Al-Si Alloys as Function of Alloy Composition and Modification. Metallurgical and Materials Transactions A: Physical Metallurgy and Materials Science, 43(12), 4846-4858. https://doi.org/10.1007/s11661-012-1308-0

\section{General rights}

Copyright and moral rights for the publications made accessible in the public portal are retained by the authors and/or other copyright owners and it is a condition of accessing publications that users recognise and abide by the legal requirements associated with these rights.

- Users may download and print one copy of any publication from the public portal for the purpose of private study or research.

- You may not further distribute the material or use it for any profit-making activity or commercial gain

- You may freely distribute the URL identifying the publication in the public portal 


\title{
Feeding and Distribution of Porosity in Cast Al-Si Alloys as Function of Alloy Composition and Modification
}

\author{
NIELS SKAT TIEDJE, JOHN A. TAYLOR, and MARK A. EASTON \\ Unmodified, Na-modified, and Sr-modified castings of Al-7 pet Si and Al-12.5 pct Si alloys \\ were cast in molds in which it was possible to create different cooling conditions. It is shown \\ how solidification influences the distribution of porosity at the surface and the center of the \\ castings as a function of modification and $\mathrm{Si}$ content in sand- and chill-cast samples. Eutectic \\ modification, Si content, and cooling conditions have a great impact on the distribution of \\ porosity. Unmodified and Na-modified castings are more easily fed with porosity tending to \\ congregate near the centerline of the casting, while Sr-modified castings solidify in a mushy \\ manner that creates a more homogeneous distribution of porosity in the casting. The amount of \\ porosity was highest in the Sr-modified alloys, lower in the Na-modified alloys, and lowest in the \\ unmodified alloys. The size of the porosity-free layer and the effectiveness of the feeders were \\ greater in the castings made with the steel chills due to the increased thermal gradients and \\ consequent increase in the directionality of solidification.
}

DOI: $10.1007 / \mathrm{s} 11661-012-1308-0$

(C) The Minerals, Metals \& Materials Society and ASM International 2012

\section{INTRODUCTION}

AL-SI alloys are commonly used for the manufacture of a wide range of commercial products. They are generally characterized by good castability; i.e., they flow well in the mold and reproduce the mold geometry and detail well with minimal casting defects. With the use of properly designed gating and feeding systems, it is relatively easy to make sound castings that have good mechanical properties. ${ }^{[1]}$ As such, Al-Si alloys with Si content ranging from 5 to 13 pct have been popular for many decades. All of these alloys form an Al-Si eutectic at the end of solidification, the amount depending on the $\mathrm{Si}$ content. At 2 pct $\mathrm{Si}$ (lower than typical foundry levels), the alloy contains almost entirely $\alpha$-Al phase, whilst at 12 to $13 \mathrm{pct} \mathrm{Si}$, the alloys are almost completely Al-Si eutectic. ${ }^{[2]}$

The amount, grain size, and morphology of the primary $\alpha$-Al phase have been shown to be important to the castability of alloys. ${ }^{[1,3-5]}$ In addition, the role of eutectic modification, including the influence on eutectic

NIELS SKAT TIEDJE, Associate Professor, is with the Department of Mechanical Engineering, Technical University of Denmark (DTU), DK-2800 Kgs. Lyngby, Denmark. Contact e-mail: nsti@mek. dtu.dk JOHN A. TAYLOR, Associate Professor, is with the CAST Co-operative Research Center, School of Mechanical \& Mining Engineering, The University of Queensland, Brisbane 4072, Australia. MARK A. EASTON, Program Manager, is with the CAST Co-operative Research Centre, Department of Materials Engineering, Monash University, Melbourne 3800, Australia.

Manuscript submitted October 7, 2011.

Article published online July 14, 2012 cell* size and morphology, has also been shown to have

\begin{abstract}
*To avoid confusion, in this article, the term "grain" (grain size, grain shape/morphology, etc.) will be used exclusively to describe a discrete entity of primary $\alpha$-Al phase, i.e., dendritic or rosette-like, equiaxed or columnar in form, or formed from a unique nucleation event. The term "cell" (cell size, cell shape/morphology, etc.) will be exclusively used to describe a discrete entity of Al-Si eutectic, i.e., the related $\mathrm{Al}$ and $\mathrm{Si}$ components, formed from a unique eutectic nucleation event.
\end{abstract}

a very significant effect on the presence of casting defects. $^{[6-9]}$

The Al-Si eutectic is relatively coarse with highly faceted $\mathrm{Si}$ particles in untreated (unmodified) alloys. Therefore, it is common in the industry to add chemical modifiers, typically $\mathrm{Na}$ or $\mathrm{Sr}$, in small amounts to $\mathrm{Al}-\mathrm{Si}$ alloys to refine the size and change the shape of the $\mathrm{Si}$ particles, which has been shown to improve the mechanical properties, especially the ductility of the alloys. ${ }^{[1,10]}$ Modification increases ductility from approximately 1 pct to up to 10 pct in well-treated alloys cast under the best possible conditions. ${ }^{[1]}$ Other elements such as $\mathrm{Sb}$ and $\mathrm{Bi}$ are also known to be modifiers; however, they are not readily available in forms that are useful to the industry. ${ }^{[10-12]}$

Sodium is an excellent modifier that has been used for decades in the industry. Recent research has shown that it acts to reduce the number of nuclei available for the formation of eutectic cells, and as a result, the $\mathrm{Na}$ modified eutectic grows at higher undercooling (i.e., lower temperature) than the unmodified eutectic. Thermal analysis has shown that there is no, or very little, recalescence at the beginning of eutectic solidification and that the eutectic plateau is flat; therefore, the growth rate is uniform at a constant undercooling. ${ }^{[8]}$ 
Strontium has been proven to work in a similar fashion to $\mathrm{Na}$, reducing the available number of nuclei for eutectic cells. ${ }^{[13-15]}$ However, the effect is different. In Sr-modified alloys, eutectic solidification is preceded by an undercooling of approximately $5 \mathrm{~K}$ followed by recalescence and eutectic solidification. Due to recalescence, the eutectic grows at varying velocity, and the shape and scale of the eutectic silicon varies from the center of the eutectic cell to the intercellular region as described by McDonald et al. ${ }^{[6,16]}$

It has been shown that there are fundamental differences in the distribution of porosity in unmodified, $\mathrm{Na}-$, and Sr-modified Al-Si based alloys and castings. ${ }^{[8,16,17]}$ These differences can be related to the way that the eutectic nucleates and grows in the three different types of materials. The eutectic cell size in unmodified castings is small, while in modified castings it is larger and dependent on the concentration of modifier added. Unmodified and Na-modified castings tend to be more shell forming during solidification than their Sr-modified counterparts; therefore, the distribution of porosity is different. Unmodified castings are easier to feed and contain little porosity. In Na-modified castings, large intercellular pores are found within a large volume at the center of the casting, while in $\mathrm{Sr}$-modified castings, pores are found evenly distributed in the casting. ${ }^{[17]}$

While much research in recent years has been directed towards understanding how modifiers influence the nucleation and growth of the eutectic in Al-Si alloys, it is important to combine that knowledge with how $\mathrm{Si}$ content, modification, and cooling conditions interact with each other to influence solidification, feeding, and distribution of porosity in castings. Such knowledge is important to designers and producers of aluminum castings because it is well known that the casting geometry and the application of feeders to castings are crucial to the quality of the final product. ${ }^{[1,18,19]}$ If the casting design does not allow paths for feeding at certain critical points of solidification, porosity and/or shrinkage defects will form in the castings. Porosity, together with shape, size, and distribution of eutectic Si particles, can also greatly influence casting machinability, especially tool life and the quality of machined surfaces. ${ }^{[2]}$

The present work does the following: (1) systematically investigates the effect of $\mathrm{Si}$ content and type of modification on feeding, (2) investigates porosity formation in Al-Si alloys cast in both sand molds between steel chills, and (3) provides an overview of how the method of modification, alloy composition, and choice of mold material influence these factors.

\section{EXPERIMENTAL PROCEDURE}

\section{A. Casting Layout and Molding}

Test castings were produced using a sand mold assembly designed with three separate plates, each $15 \times 120 \times 160 \mathrm{~mm}$, and each with a separate feeder attached. Both of the large faces (i.e., $120 \times 160 \mathrm{~mm}$ ) of the plate cavities were made with exchangeable cores. In these experiments, the cores were either made of steel or the same silica sand and binder as the rest of the mold.
Each mold assembly contained one plate cavity with a sand core on either side, another with a steel chill core on both sides, and the third with sand on one side and a steel chill on the other. The latter of these are not reported on in this paper.

The mold assembly was made of four parallel sections: The bottom section contained the three runners, and located above this was a section containing three feeders and a ceramic foam filter at the base of the down-sprue. This was followed by the main section in which the cores were inserted to form the three plate cavities. Finally, there was a top section containing a pouring cup that served to close the end of the plate cavities. A tapered down sprue extended through the sections from the pouring cup to the runners.

These sections and the sand cores were made from silica sand with an average grain diameter of $0.20 \mathrm{~mm}$, sieved, washed, and dried. The binder was an alkaline phenolic resin binder cured with an organic liquid ester.

The gating system was made such that the melt entered the plate cavities from below (i.e., an underpouring system) through the feeders, after passing through a 30 p.p.i. (pores per inch) ceramic foam filter. This ensured that the feeders were kept hot, while the far end of the plates were the coolest.

The mold assemblies were placed in a rotatable steel fixture that helped to hold the molds closed, and at the same time, they made it possible to invert the mold immediately after pouring. This was done so that the feeders were relocated to the top of the casting during solidification so that gravity feeding could take place. With the cooler metal now located at the bottom of the plates, this meant that the castings solidified directionally from bottom to top. Rotation of the assembly occurred in a direction that prevented loss of metal from the feeders and plate cavities. Figure 1 shows the mold assembly and a casting with feeders and runners attached. In this figure, the top part of the mold has not been mounted.

\section{B. Melting and Casting}

In this work two different alloys were studied: Al7 pct Si and Al-12.5 pet Si. The first was made from a master alloy with the composition given in Table I. Apart from $\mathrm{Al}$ and $\mathrm{Si}$, it also contains 0.11 pet $\mathrm{Fe}$ as impurity. The 12.5 pet $\mathrm{Si}$ alloy was made by adding metallurgical grade $\mathrm{Si}$, greater than 99 pct pure to the Al-7 pet Si alloy.

The sodium used for modification was extracted from sealed capsules of pure $\mathrm{Na}$, which are normally used for industrial modification of foundry alloys. Capsules were opened immediately before use, and a suitable piece was cut and weighed. The target $\mathrm{Na}$ content was $250 \mathrm{ppm}$ in the 7 pct Si alloy and $300 \mathrm{ppm}$ in the Al-12.5 pet Si alloy to reflect the amount of $\mathrm{Si}$ to be modified. After degassing the melt with argon, the solid $\mathrm{Na}$ was pressed into a conical coated-steel plunger and forced to the bottom of the melt while it dissolved.

An Al-10 pct $\mathrm{Sr}$ master alloy was used for $\mathrm{Sr}$ modification. The targeted $\mathrm{Sr}$ content was 250 and $350 \mathrm{ppm}$ for the 7 and $12.5 \mathrm{pct} \mathrm{Si}$ alloys, respectively. 

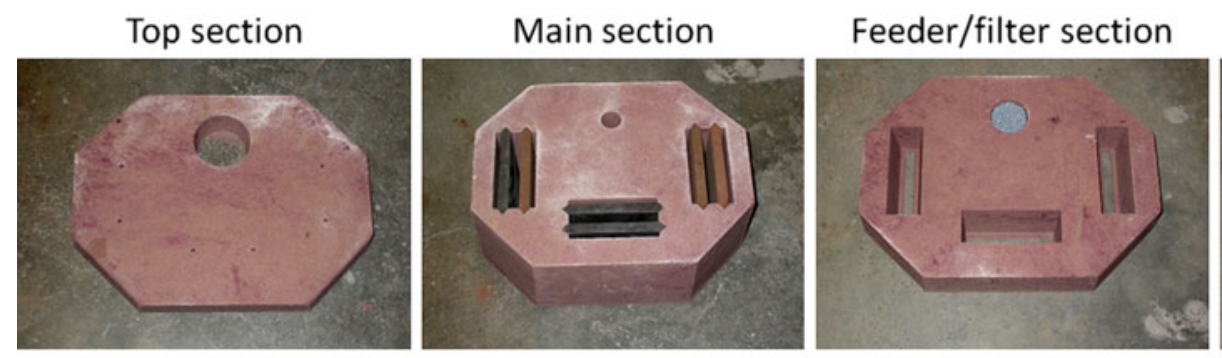

\section{Bottom section}
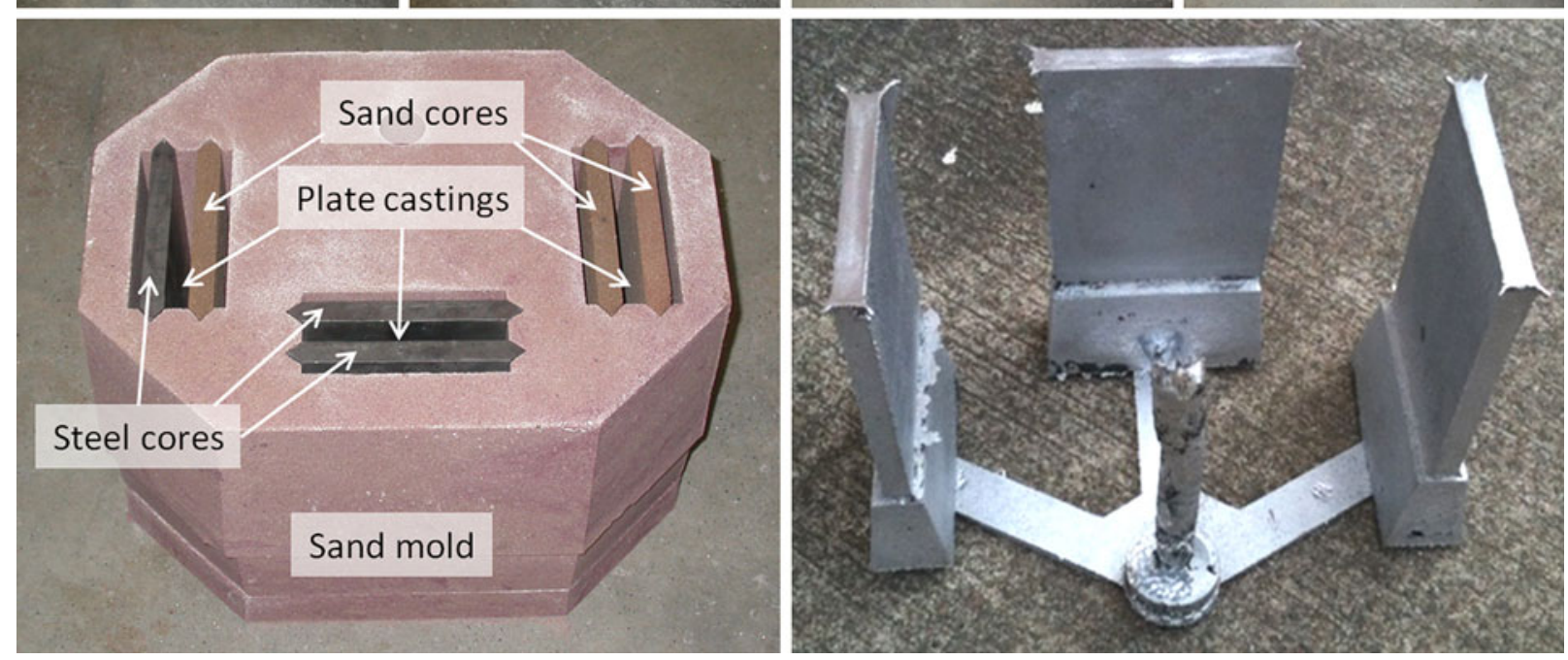

Fig. 1-The top row shows the four sections of the mold. Bottom row, left, part of the mold assembly showing plate cavities with various face cores. Bottom row, right, the triplate casting with gating system and feeders still attached. The casting on the right is shown as it is poured. Immediately after pouring, the assembly and casting are inverted so that the feeders become located above the plates.

Table I. Composition of Al-7 pet Si Master Alloy (weight percent) as Given by the Manufacturer

\begin{tabular}{lccc}
\hline $\mathrm{Al}$ & $\mathrm{Fe}$ & $\mathrm{Si}$ & $\begin{array}{c}\text { Other } \\
\text { Elements }\end{array}$ \\
\hline 92.77 & 0.11 & 7.08 & 0.04 \\
\hline
\end{tabular}

Suitable pieces were cut from the master alloy and added to the melt after degassing.

Alloys were melted and prepared as approximately $5 \mathrm{~kg}$ batches in a $20-\mathrm{kW}$ drop coil induction furnace. The Al-7 pct $\mathrm{Si}$ alloy was heated to $1003 \mathrm{~K} \pm 10 \mathrm{~K}$ $\left(730{ }^{\circ} \mathrm{C} \pm 10^{\circ} \mathrm{C}\right)$ and held at that temperature while degassed with Ar for 20 minutes at a flow rate of $2 \mathrm{~L} / \mathrm{min}$. The Al-12.5 pct $\mathrm{Si}$ alloy was heated to $978 \mathrm{~K} \pm 10 \mathrm{~K}\left(705^{\circ} \mathrm{C} \pm 10{ }^{\circ} \mathrm{C}\right)$ and held at that temperature while degassing with $\mathrm{Ar}$ for 20 minutes. The pouring temperatures were $1003 \mathrm{~K} \pm 5 \mathrm{~K}\left(730^{\circ} \mathrm{C} \pm\right.$ $\left.5{ }^{\circ} \mathrm{C}\right)$ and $978 \mathrm{~K} \pm 5 \mathrm{~K}\left(705^{\circ} \mathrm{C} \pm 5{ }^{\circ} \mathrm{C}\right)$, respectively; i.e., each alloy was superheated to approximately $130 \mathrm{~K}$ $\left(-143{ }^{\circ} \mathrm{C}\right)$ above its respective liquidus temperature. The melt surface was carefully skimmed before pouring into the prepared sand molds.

\section{Metallographic Analysis}

Samples were cut from positions along the centerline of the $120 \times 160 \mathrm{~mm}$ face, in particular, one sample just below the feeder and one at the center of the plate (Figure 2). These two locations were chosen because the

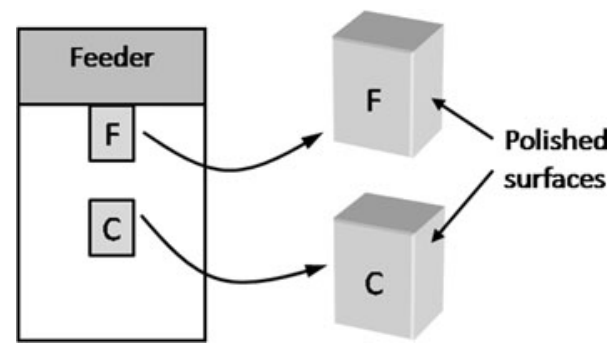

Fig. 2-Diagram showing where samples were taken from the plates. Samples were polished on a plane perpendicular to the largest face to reveal a complete cross section of the plates.

first should be a location with ideal feeding conditions, and the second is a position where it is more likely to find porosity.

Samples were mounted in resin, mechanically ground, and polished and then finished with $0.04-\mu \mathrm{m}$ colloidal silica. Macro photographs were taken using a stereo microscope with a circular light source at low magnification. Micrographs at low-to-medium magnification were taken using a Reichert Polyvar (Reichert Microscope Services, Depew, NY) optical microscope.

The total area of porosity on the samples was measured from the macrographs using Leica Q-Win image analysis software (Leica Microsystems, Wetzlar, Germany). Using a circular light source, pores appear white on a dark background and were easily detected by the software. The pixel size was $1 \mu \mathrm{m}$. White areas consisting of less than 20 pixels were omitted. This limit 
was chosen because the total area of porosity changed little, and the number of particles counted increased rapidly as the limit was lowered. The additional particles counted as the limit was lowered were typically either coarse Si particles or optical artefacts due to imperfect lighting or variations in polishing. The area analyzed for each condition was $14 \times 16 \mathrm{~mm}$, covering almost the full width of the casting.

\section{RESULTS}

\section{A. Microstructure}

It is well known ${ }^{[1,2]}$ that modifiers are added to modify the structure of the Si component of the Al-Si eutectic. Microstructures from the current alloys are shown in Figures 3 through 6. To the left in these figures (inserts (a), (d). and (g)) it is seen that the unmodified structure contains coarse, facetted eutectic Si particles. Some modification is observed at the faster cooling rates near the surface of the samples cast in the molds containing steel cores (Figure 5(d)). The effect of cooling rate is more pronounced in the 12.5 pct Si alloy than in the 7 pct $\mathrm{Si}$ alloy. It may be seen by comparing Figures 5(a) with 5(d) and 6(a) with 6(d), but the enlarged sections (Figures $6\left(g_{1}\right)$ and $\left(g_{2}\right)$ ) shows the effect of cooling rate in the 12.5 pct $\mathrm{Si}$ alloy clearer.
The Na-modified eutectic, actually a fibrous structure in three dimensions (see inserts (b), (e), and (h) in Figures 3 through 6) is finer and more uniform than the Sr-modified eutectic (inserts (c), (f), and (i) in Figures 3 through 6). Furthermore, the structure and scale of the Na-modified eutectic does not vary much from the chilled surface to the slower cooled interior, or from the steel-core cast samples to the sand-core cast samples (compare inserts (b), (e), and (h) in Figures 3 and 4 with that in Figures 5 and 6).

Coarser $\mathrm{Si}$ particles are found even in the modified structures near the eutectic cell boundaries, particularly at the center of the Sr-modified samples. This is shown in the enlarged images in Figures 3(i), 4(i), 5(i), and 6(i). On Figures 6(h) and (i), it is possible to see the slightly larger Si particles outlining the eutectic cell boundaries in the $\mathrm{Na}$ - and Sr-modified 12.5 pct Si alloy. It is clear from the images that the Na-modified $\mathrm{Si}$ is more uniform than it is in the Sr-modified alloy. The two inserts also indicate the difference in cell size between Na- and Sr-modified alloys. These coarse particles are more easily seen in the near eutectic castings because of the higher Si content and because there are less primary dendrites that hide the boundaries of the eutectic cells; compare insert (i) in Figures 3 through 6.

The needle-shaped particles that are seen at the center of Figures 4(b) and (c) and 6(j) were analyzed in a

\section{Al $7 \% \mathrm{Si}$, unmodified}
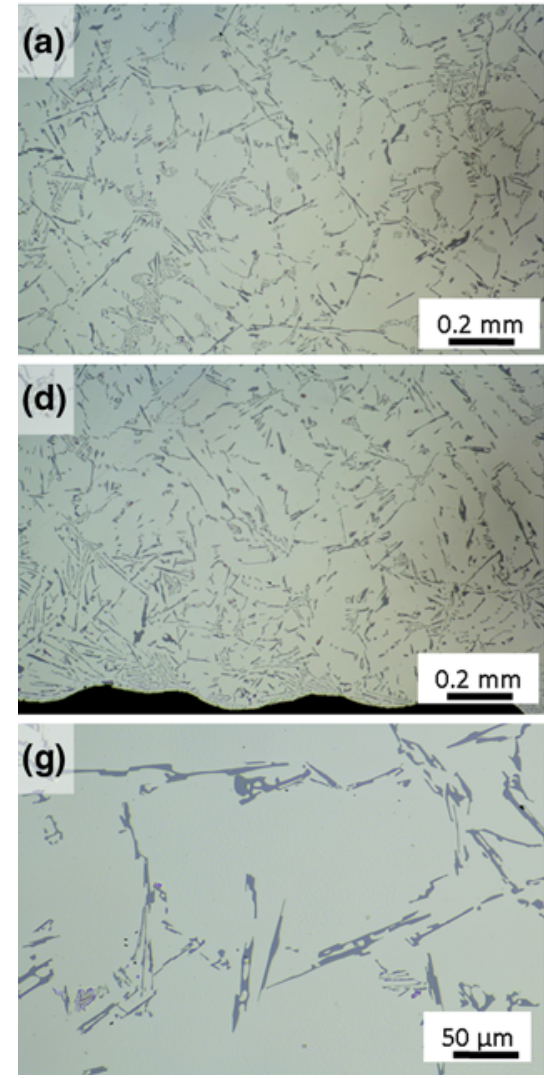

Al $7 \% \mathrm{Si}$, Na modified
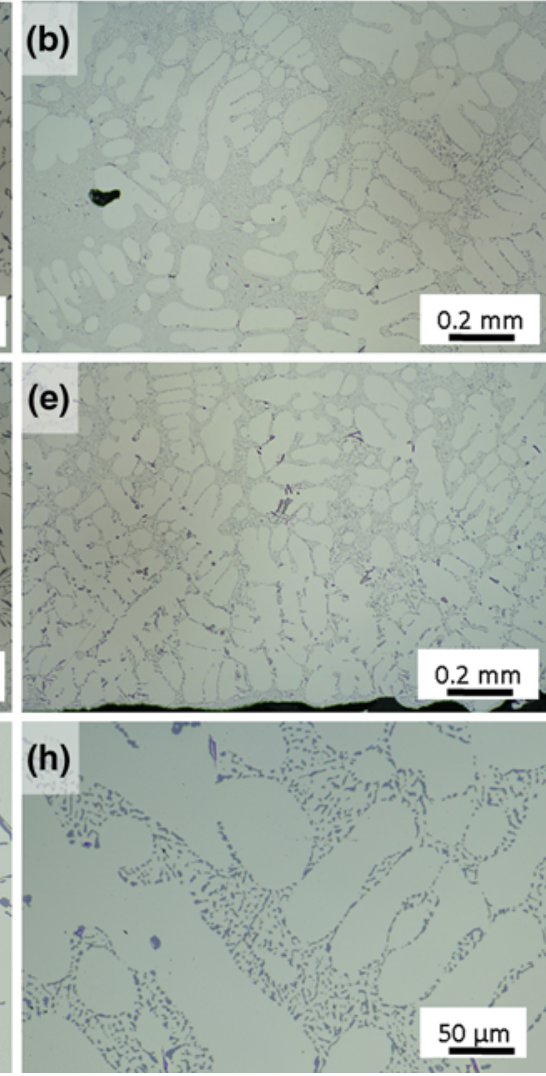

Al $7 \%$ Si, Sr modified
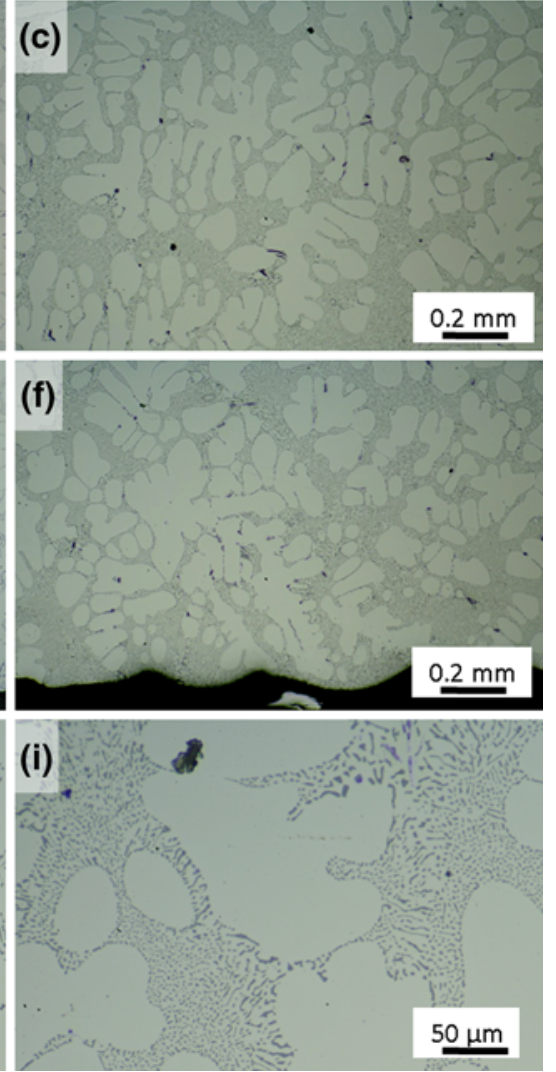

Fig. 3-Micrographs of samples taken from position $\mathrm{C}$ in the sand-cast plates of the Al-7 pct Si alloy. Top row images ( $a$, $b$, $c$ ) are from the centerline of the plates; middle row images $(d, e, f)$ are from near the cast surface. Bottom row images $(g, h, i)$ are enlarged sections of $(\mathrm{a}, \mathrm{b}$, and c), respectively. 
Al $12.5 \%$ Si, unmodified
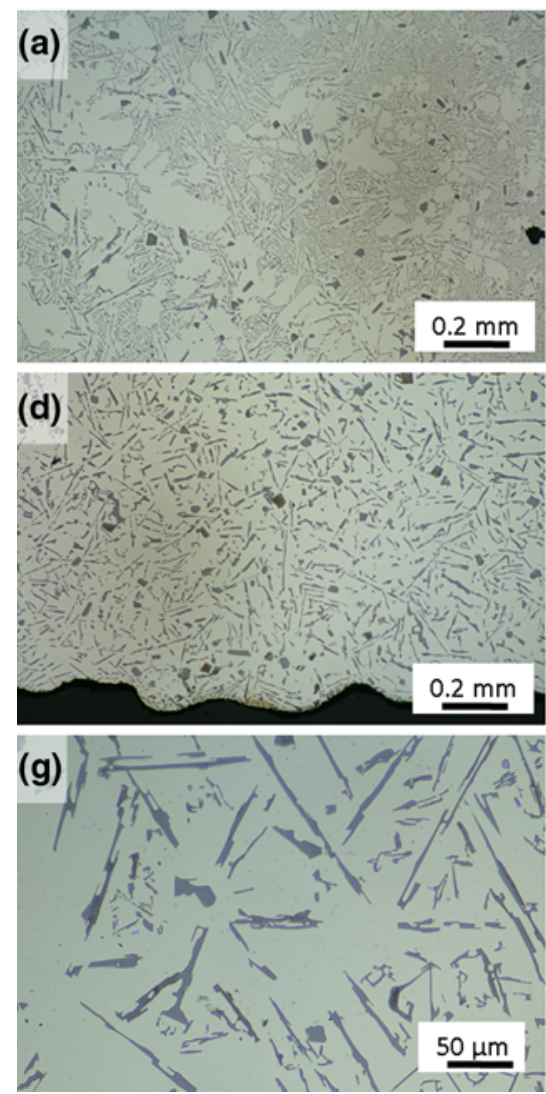

Al $12.5 \%$ Si, Na modified

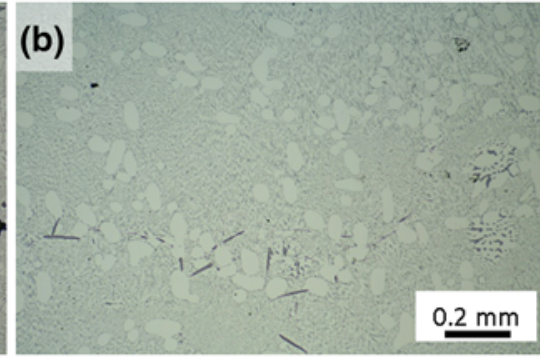

(e)
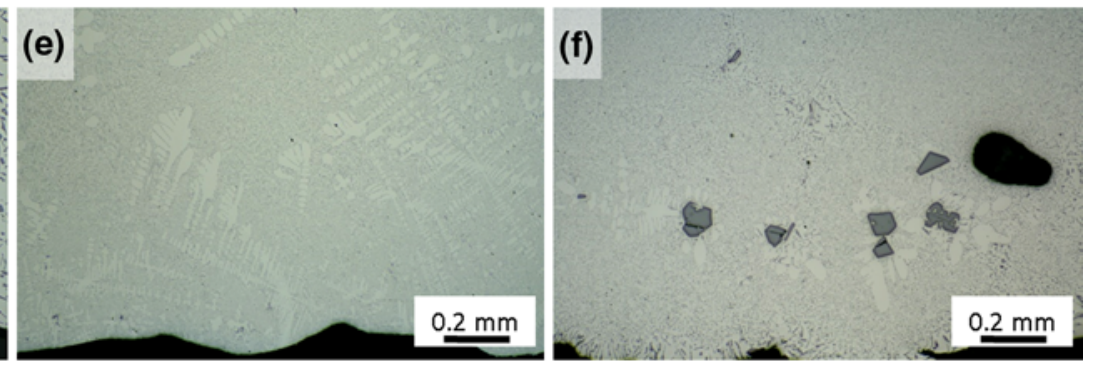

(h)

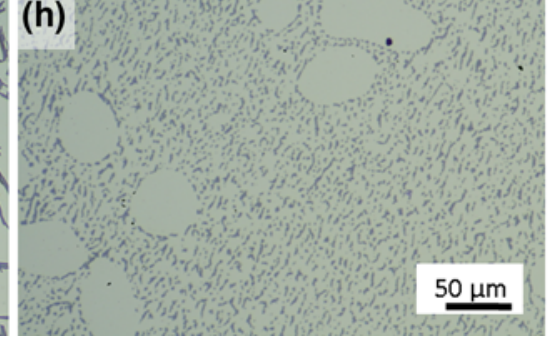

Al $12.5 \% \mathrm{Si}$, Sr modified
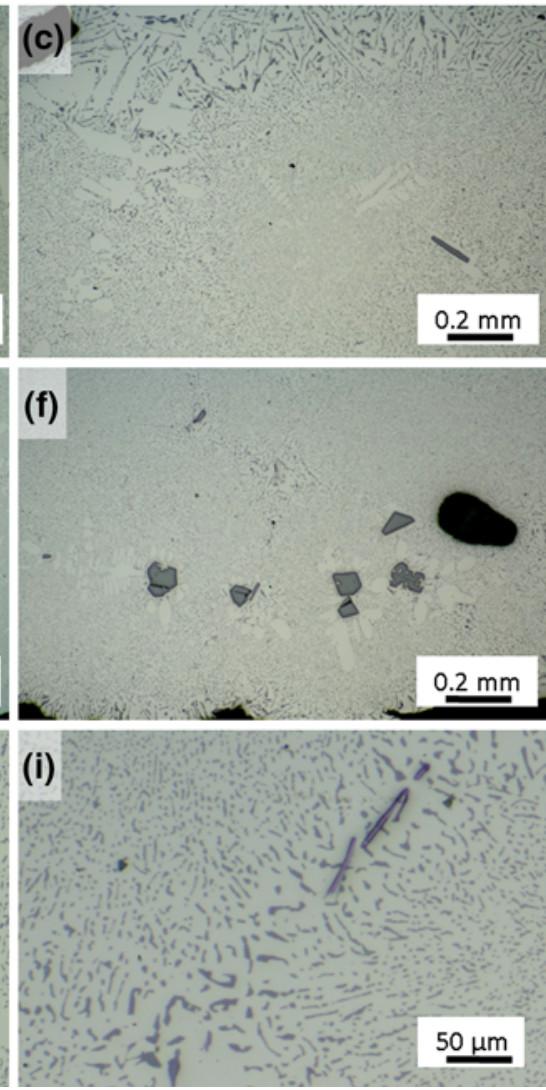

Fig. 4-Micrographs of samples taken from position $\mathrm{C}$ of the sand-cast plates of the Al-12.5 pct Si alloys. Labeling is the same as for Fig. 3.

scanning electron microscope with an energy-dispersive $\mathrm{X}$-ray spectroscopy. They contain $\mathrm{Al}, \mathrm{Si}$, and Fe and are likely to be $\beta-\mathrm{Al}_{5} \mathrm{FeSi}$ phase. They are found along the eutectic cell boundaries in all samples.

\section{B. Macrostructure at the Center of the Plate}

Figure 7 shows macro photographs of the full cross section from the center of the plates cast in a sand mold. The vertical bright lines at either side of the images come from light reflecting off the edge of the samples; thus, they indicate the surfaces of the plates. Bright white spots are porosity. The variation in shading on the macro photographs is mainly due to variation in the scale of the eutectic $\mathrm{Si}$, although variation in dendrite arm spacing also has a minor influence. Typically, coarse Si particles are dark.

The samples contain coarse $\alpha-\mathrm{Al}$ dendritic grains (more in Al-7 pet Si than in Al-12.5 pet Si) and Al-Si eutectic cells that fill the space in between the dendrites. The structure of the unmodified samples is very uniform through the thickness of the plate, as seen in Figures 7(a) and (d). In Figure 8, which shows magnified sections of Figures 7(b) and (f) (Na-modified alloys), dark-colored dendrites are seen to grow from the casting surface (i.e., from the left in both pictures). Eutectic cell boundaries are light gray.

In some samples, it is possible to distinguish a 1-mmto $3-\mathrm{mm}$-thick zone near the surface where fine eutectic cells indicate the position of the initial solid shell formed immediately after pouring, see Figures 7(b), (d), and (e). This layer is most pronounced in the Na-modified castings, but on closer inspection, it is also found in the unmodified castings. In some samples, Figures 7(b) and (f), which are magnified in Figure 8, the cells near the surface appear to be elongated, while in others, Figures 7(d) and (e), there is a more closely packed population of more rounded cells.

In the sand-cast, Sr-modified Al-12.5 pet Si alloy (Figure 7(f)), the solid shell layer does not exist in the same form as in the other samples. It appears that eutectic cells have nucleated in a volume near the surface of the castings but have not grown to form a solid shell. In those castings, there appears to have been a porous or mushy layer rather than an actual shell with the amount of liquid between the eutectic cells not varying much from surface to center at a given time.

Macro photographs of the plates cast in molds with steel chills show more distinct features (Figure 9). In these samples, there is always a thin chill zone evident along the surface where dendritic grains with random orientation have nucleated and grown. From that layer, dendrites grow into the melt, parallel to the heat flow but in an opposite direction to it. A magnified picture of the surface of a Sr-modified Al-12.5 pct Si casting is shown in Figure 10. It shows the thin zone along the surface of the casting with many fine dendrites. Moving towards the casting center, the fraction of dendrites 
Al $7 \% \mathrm{Si}$, unmodified
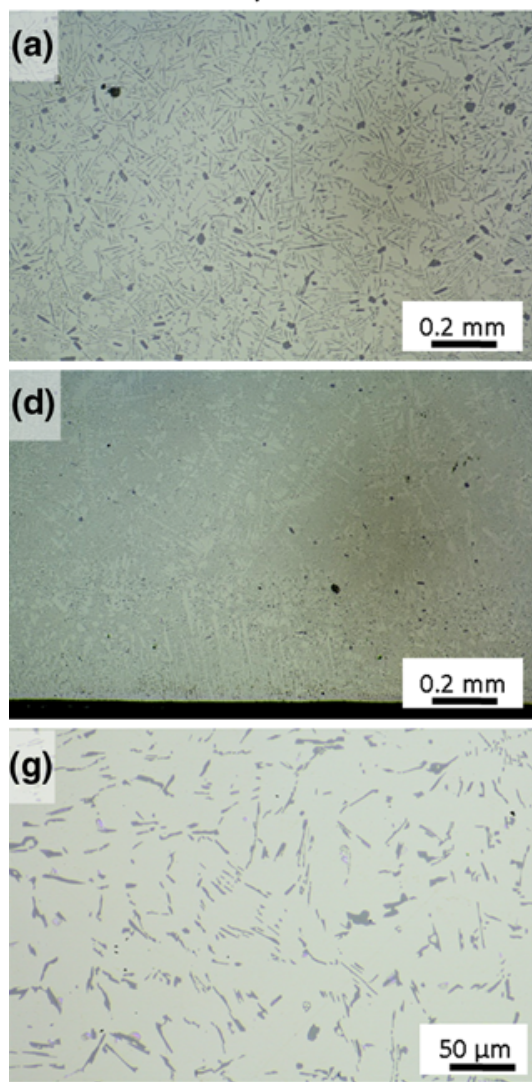

Al $7 \% \mathrm{Si}$, Na modified
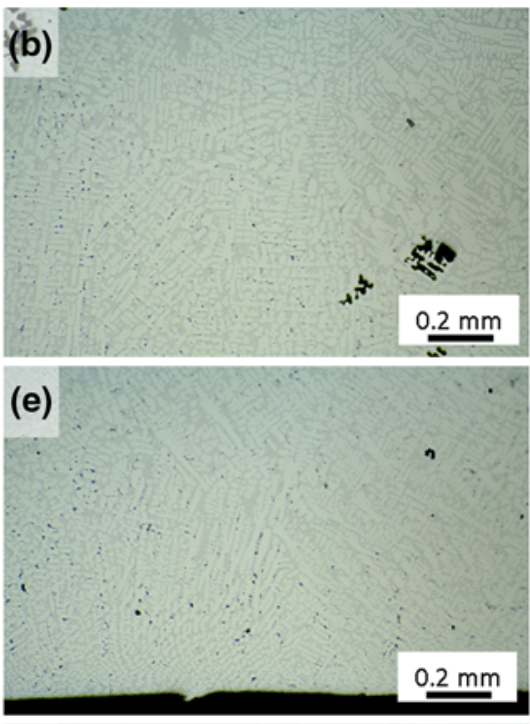

(h)

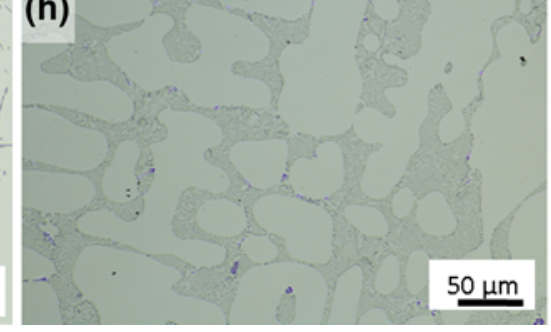

Al $7 \%$ Si, Sr modified
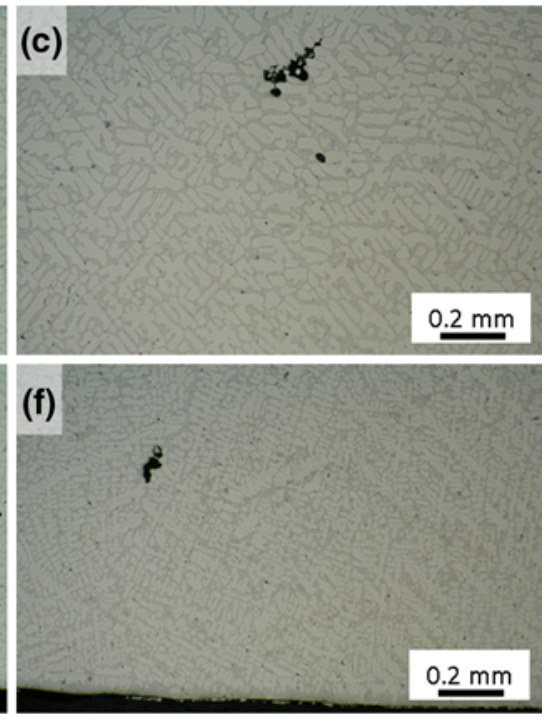

(i)

Fig. 5-Micrographs of samples taken from position $\mathrm{C}$ in the Al-7 pct Si alloys cast between steel cores (chills). Labeling is the same as for Fig. 3.

reduces, the dendrites become coarser, and they cease growing directionally towards the centerline of the casting.

In most of the samples taken at the center of the plates (position " $\mathrm{C}$ " in Figure 2), in particular those cast with chills, there is, at some distance from the surface, a transition from directional to equiaxed solidification of the primary Al phase. This is commonly termed the columnar-to-equiaxed transition (CET). This transition may be seen to the right in Figure 10. The transition zone is irregular. In the macrographs of the unmodified castings, it is not possible to see the transition, but observation using an optical microscope at higher magnification confirms that it exists.

\section{Macrostructure Near the Feeder}

The structures found in the samples near the feeder are similar to those found at the center of the plates. In the sand-cast plates (Figure 11), the initial shell is discernible as a thin layer close to the surface in all conditions except the Sr-modified $12.5 \mathrm{pct} \mathrm{Si}$ alloy where the shell does not appear to exist at all. The structure of the sand-cast samples at the feeder resembles the structure at the center of the plates, where the thermal mass of the feeder does not influence solidification. This suggests that the presence of a hot feeder has little effect on solidification in these castings.
Images of samples near the feeder from the plates cast with steel cores (chills) are shown in Figure 12. As with the samples taken from central locations (Figure 9), the initial shell is easily seen, although it is thinner and almost disappears at the feeder neck. In the unmodified and the Na-modified castings, it is not possible to find the equiaxed zone at the centerline of the plates, but the zone is clearly observed in the Sr-modified castings. The variations in shading from the surface in the unmodified and Na-modified castings are the result of changes in the scale of the eutectic microstructure rather than a change from cellular to equiaxed growth of the primary Al grains.

The reduced thickness of the initial shell near the feeder indicates that the combination of chills (steel cores) and a large feeder has been successful at creating a funnel-like feeding path from the feeder some distance into the casting.

\section{Distribution of Porosity}

The percentage area of measured porosity for each of the samples is shown in Figure 13. Overall, there is more porosity in the Al-7 pct $\mathrm{Si}$ alloy castings compared with the Al-12.5 pct Si castings. By considering Figures 7, 9, 11, and 12, it appears that in the 7 pct Si alloy, porosity is found between primary $\mathrm{Al}$ dendrites. As a result, the pores tend to be elongated and follow 

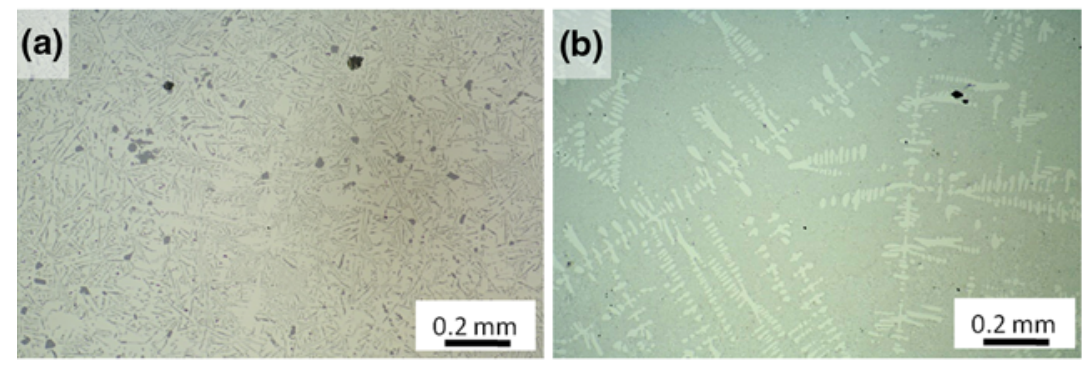

(c)

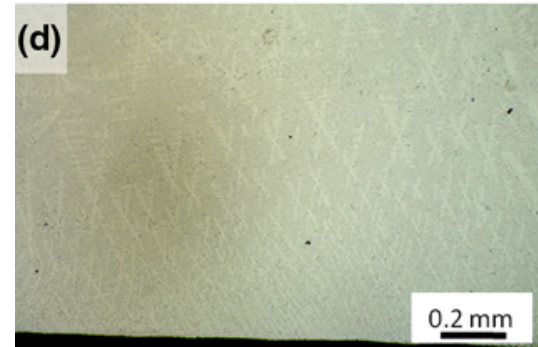

(e)

(f)
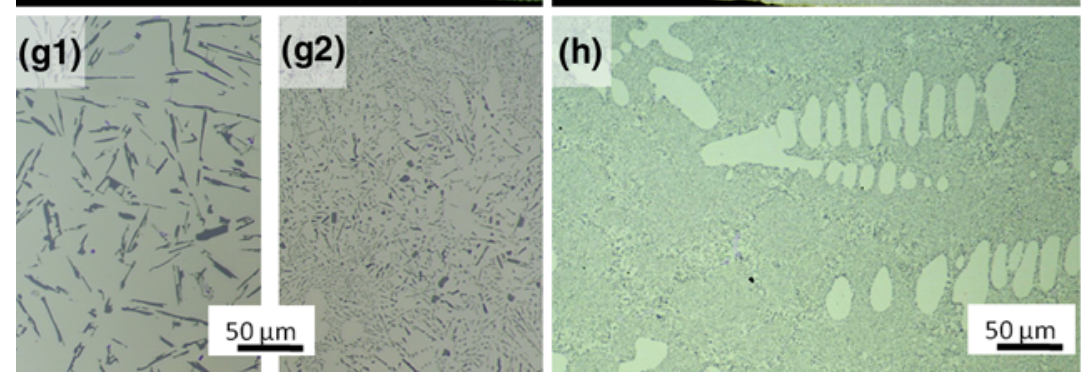

$0.2 \mathrm{~mm}$

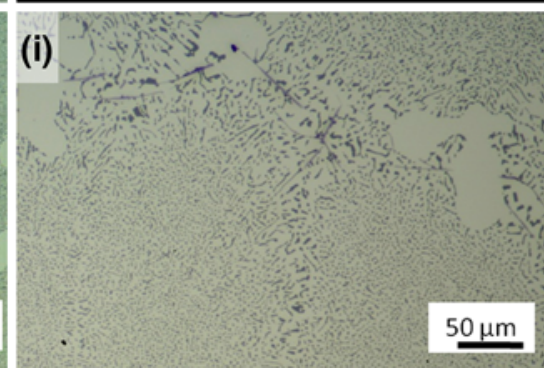

Fig. 6-Micrographs of samples taken from position $\mathrm{C}$ in the Al-12.5 pct $\mathrm{Si}$ alloys cast between steel cores (chills). Top row images $(a, b, c)$ are from the center line of the plates; middle row images $(d, e, f)$ are from near the cast surface. Bottom row images $\left(g_{1}, g_{2}, h, i\right)$ are enlarged sections of ( $\mathrm{a}, \mathrm{d}, \mathrm{b}$, and c), respectively.

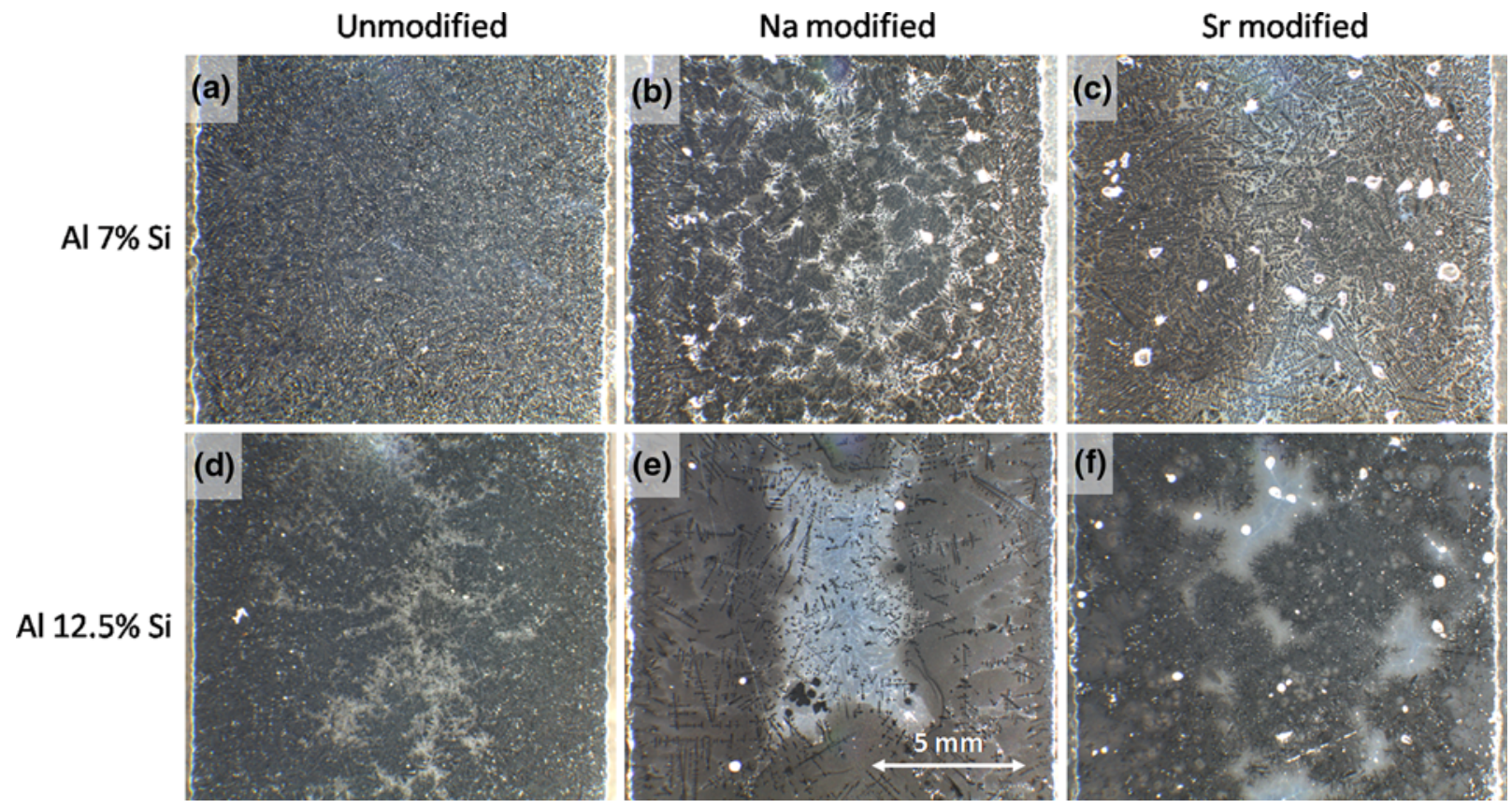

Fig. 7-Macro photographs of sample sections from sand-cored cast plates. All samples are from the center of the plate (i.e., position C in Fig. 2). Each picture shows the total width of the plates. Bright white spots are porosity. 

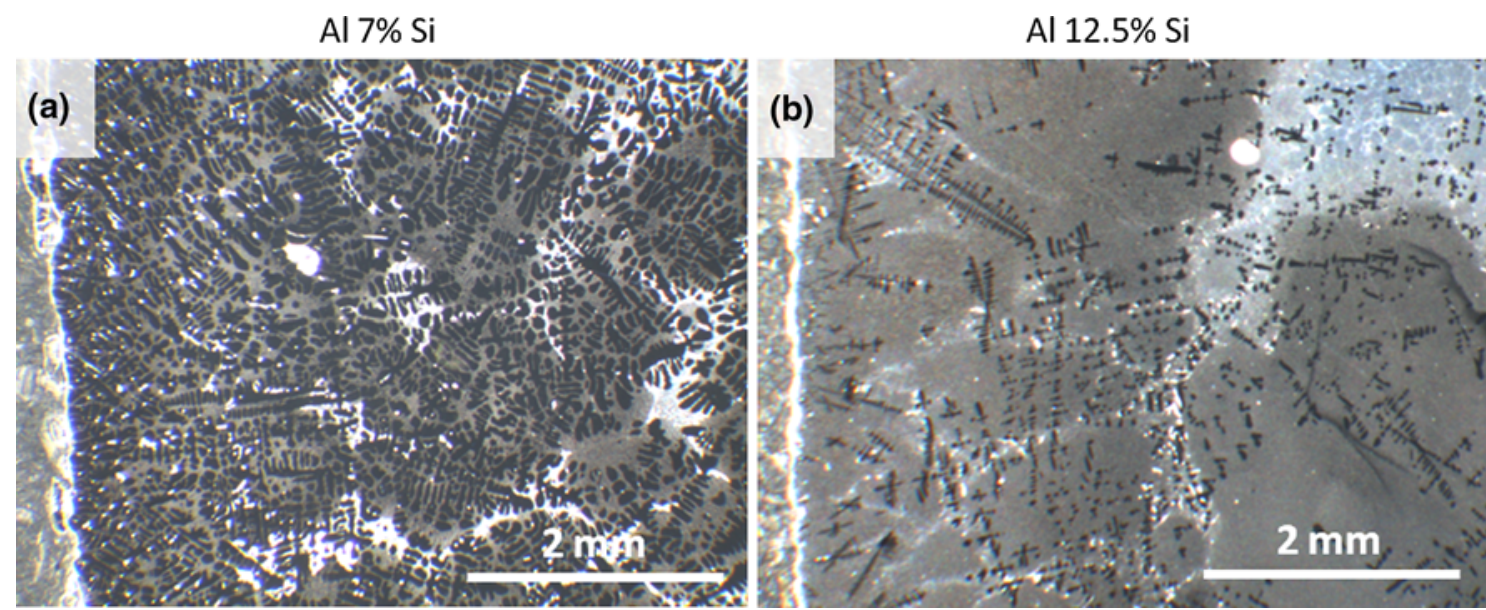

Fig. 8-Example of higher magnification macro photographs of Na-modified sand-cored castings near the surface. (a) 7 pct Si alloy (see Fig. 7(a)) and (b) 12.5 pct Si alloy (see Fig. 7(f)). Black-colored dendrites grow from the surface of the castings (i.e., from the left in the photographs) into the melt. Eutectic grains (medium gray) are separated by light gray or white contours.

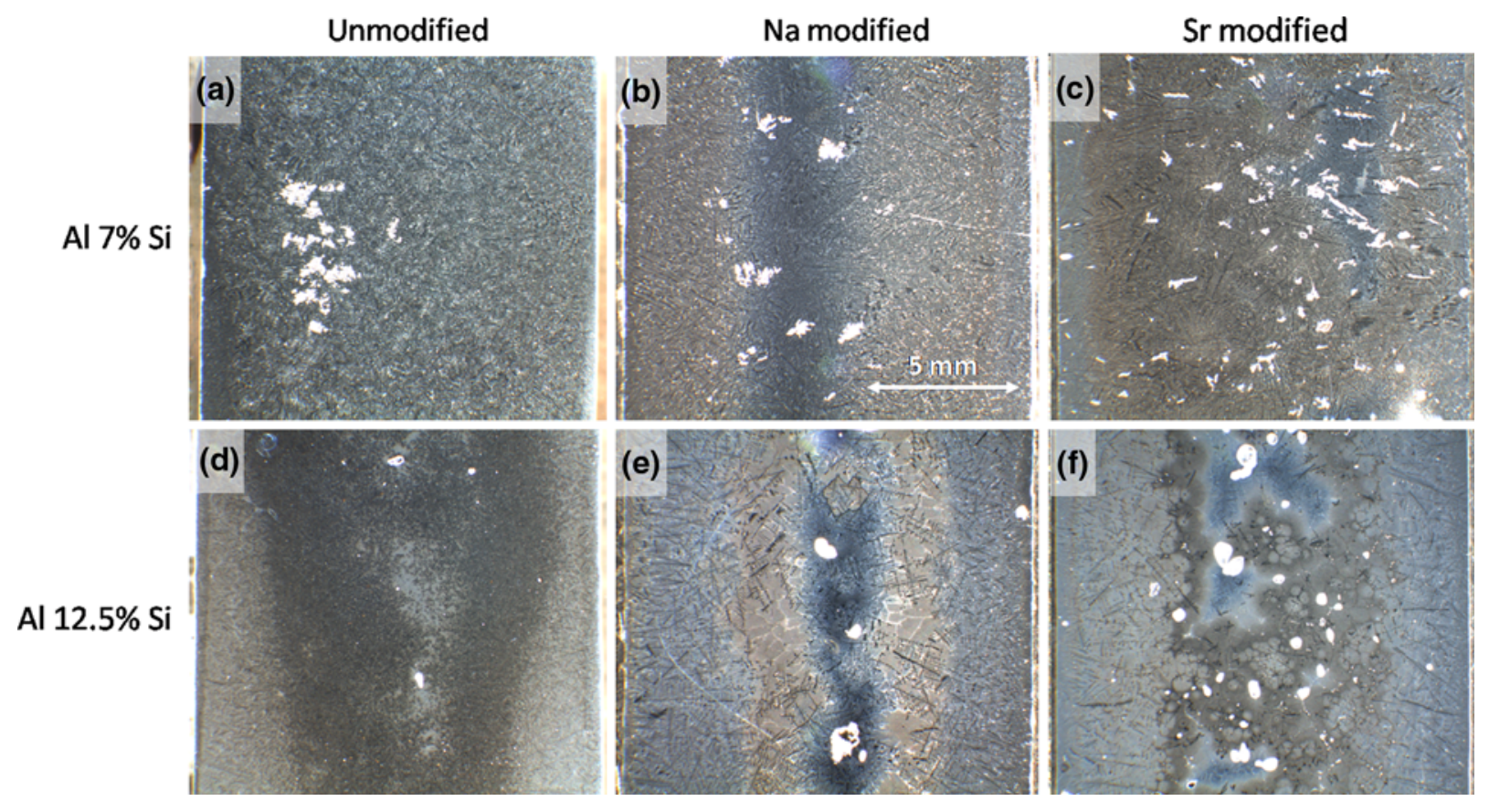

Fig. 9-Macro photographs of sample sections from plates cast between steel cores (chills). All samples are from the center of the plate (i.e., position $\mathrm{C}$ in Fig. 2). Labeling details are the same as per Fig. 7.

the outline of the dendritic grains. In the $12.5 \mathrm{pct} \mathrm{Si}$ alloy, pores are more rounded and are often located in the zone where columnar solidification has changed to equiaxed. As would be expected, the amount of porosity near the feeder is generally less than at the casting center.

It is also observed that near the feeder, the sand castings always has a higher porosity content compared with the chill castings, which is probably related to the apparently improved feeding conditions discussed in the previous section. At the plate center, this was more random, especially in the Al-7 pet Si alloy, although in the Al-12.5 pct Si alloy the chill castings had consistently greater porosity contents than the sand castings, often due to coarse porosity near the center of the casting (compare Figures 7 and 9).

There is generally very little porosity observed in the unmodified castings, some more in the Na-modified castings, while porosity is pronounced in the Sr-modified castings. The porosity that is present in the unmodified castings tends to be fine and well distributed, although large interconnected porosity was found near the center of the casting when the chill mold was used in the Al-7 pct Si alloy (Figures 9(a) and (d)). The Na-modified samples also seem to have relatively porosity-free surface regions with porosity congregated near the casting center, particularly in the chill castings (images (b) and (e) in Figures 7, 9, 11, and 12). The Sr-modified alloys have 
coarse porosity throughout the casting (images (c) and (f) in Figures 7, 9, 11, and 12).

\section{DISCUSSION}

\section{A. Effect of Microstructural and Macrostructural Features on Porosity Distribution}

It is evident that the $\mathrm{Si}$ content and the consequent amounts of $\alpha-\mathrm{Al}$ and $\mathrm{Al}-\mathrm{Si}$ eutectic, as well as the

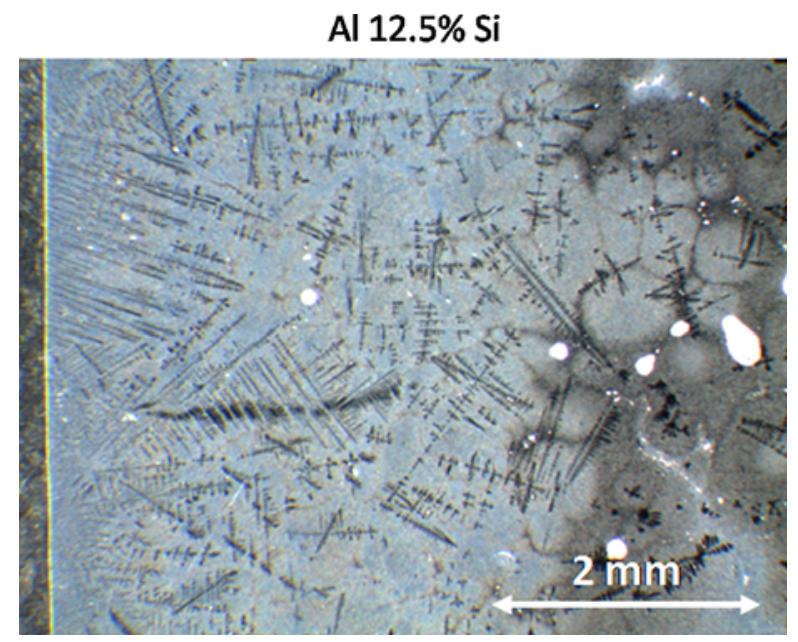

Fig. 10-Higher magnification macro photograph of sample section of $\mathrm{Sr}$-modified steel-cored (chill) casting near the surface (see Fig. 9(f)). Black-colored dendrites grow from the surface of the castings (i.e., from the left in the photographs) into the melt. Eutectic grains (light gray) are separated by dark gray contours. White areas are porosity. modification type and how it affects the growth modes of the eutectic, exert strong influences on porosity formation. However, even though the $\alpha$-Al forms before the eutectic, it is useful to consider the formation of the eutectic first for the purpose of this discussion.

It is clear that modification significantly changes not only the morphology of the eutectic Si particles but also the size of the eutectic cells. As shown in this study and in those by other authors, ${ }^{[14-17,21]}$ there are distinct changes in the growth modes and, consequently, the porosity formation between unmodified castings and those modified with $\mathrm{Na}$ and $\mathrm{Sr}$.

In the unmodified castings, individual eutectic cells are difficult to distinguish, particularly in the 7 pct $\mathrm{Si}$ alloy where the primary dendritic network interferes visually with them. However, it is clear that the eutectic cells are fine and equiaxed throughout the casting.

Modification with $\mathrm{Na}$ increases the eutectic cell size to some degree over that of the unmodified alloys. Close to the surface of the castings, the cells are slightly elongated, even in sand castings, and there is clear evidence that $\mathrm{Na}-$ modified alloys are able to form a solid shell as long as the temperature gradient is sufficiently high (Figures 7(b) and $9(\mathrm{~b})$ and (e)), as observed previously by Dahle et al. ${ }^{[21]}$ in Al-10 pct Si alloys. It can be concluded that the eutectic in Na-modified castings grows more as a solid front following behind the dendrite tips when solidification takes place in a temperature gradient. In sand molds, the necessary gradient cannot be maintained for long once solidification has begun. The center of the casting therefore solidifies as equiaxed eutectic cells between which porosity frequently forms.

Modification with $\mathrm{Sr}$ increases the eutectic cell size, and these are larger still than those in the Na-modified castings. As observed in other studies, ${ }^{[8,16]}$ the cell size is
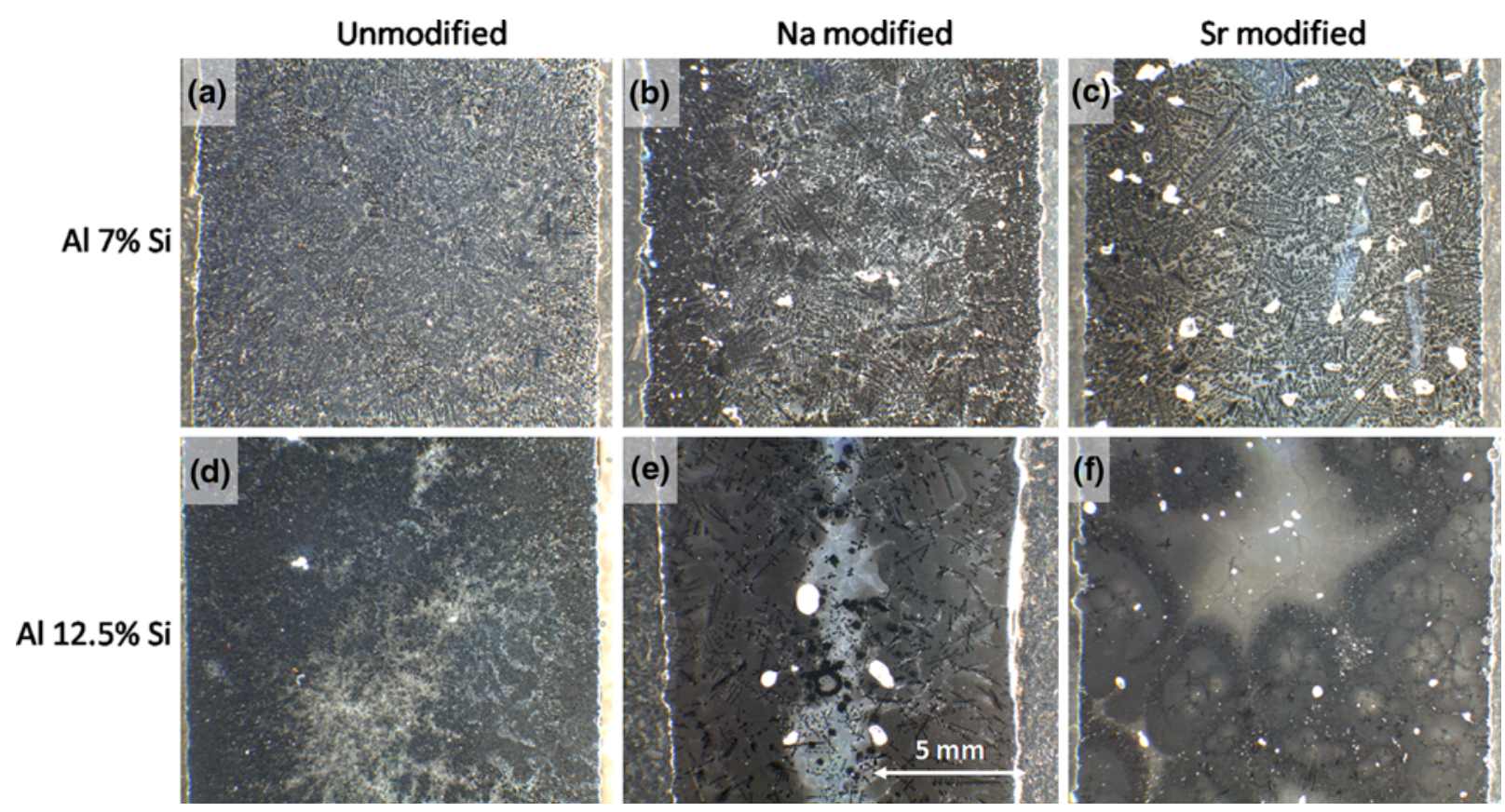

Fig. 11-Macro photographs of sample sections taken from plates cast in sand-cored molds. Samples are from close to the feeder (i.e., position F in Fig. 2), the feeder neck being $\sim 1 \mathrm{~mm}$ above the top edge of the images. Labeling details are the same as per Fig. 7. 


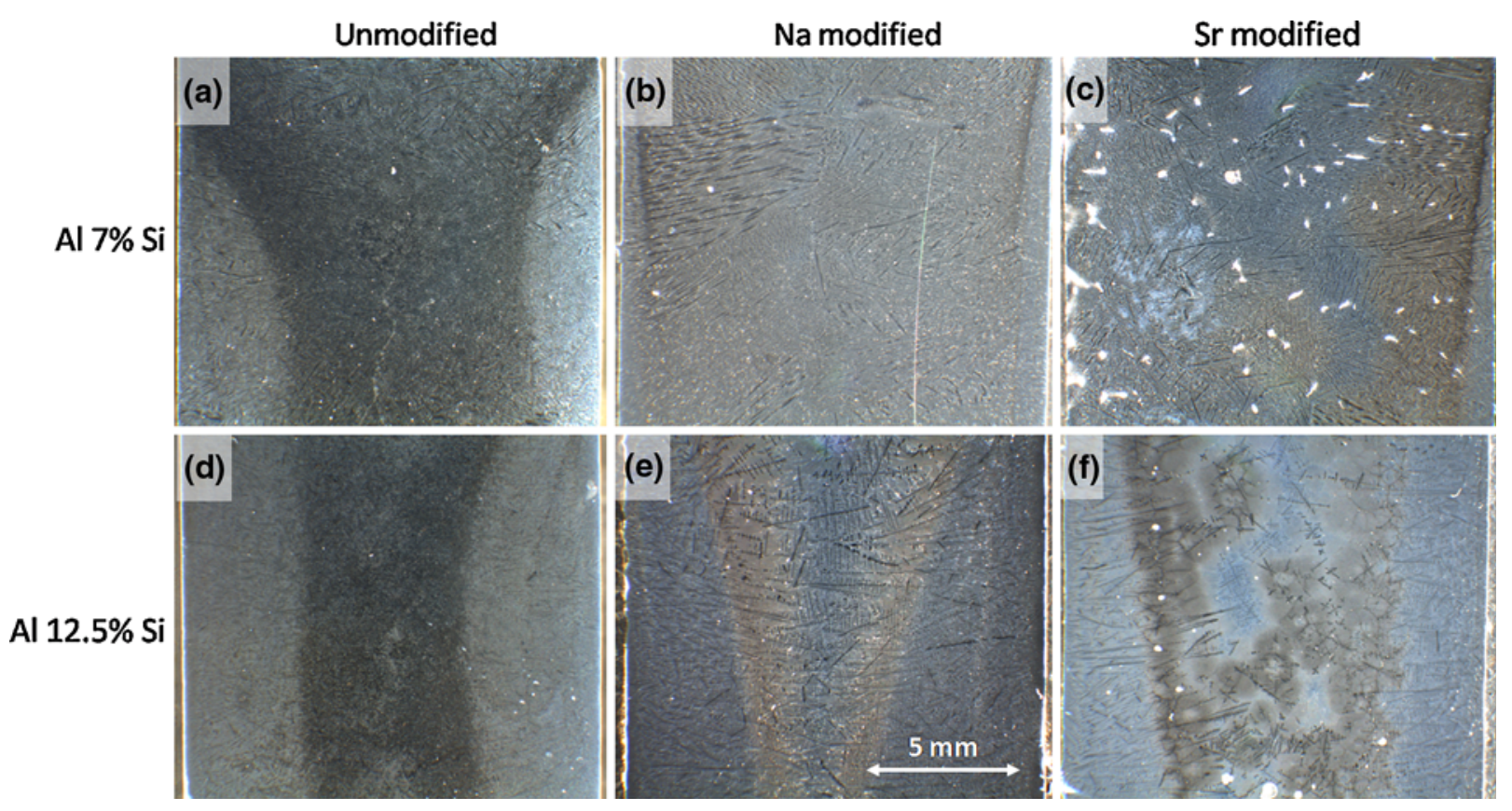

Fig. 12-Macro photographs of sample sections taken from plates cast using steel cores (chills). Samples are from close to the feeder, the feeder neck being $\sim 1 \mathrm{~mm}$ above the top edge of the images. Labeling details are the same as per Fig. 7 .
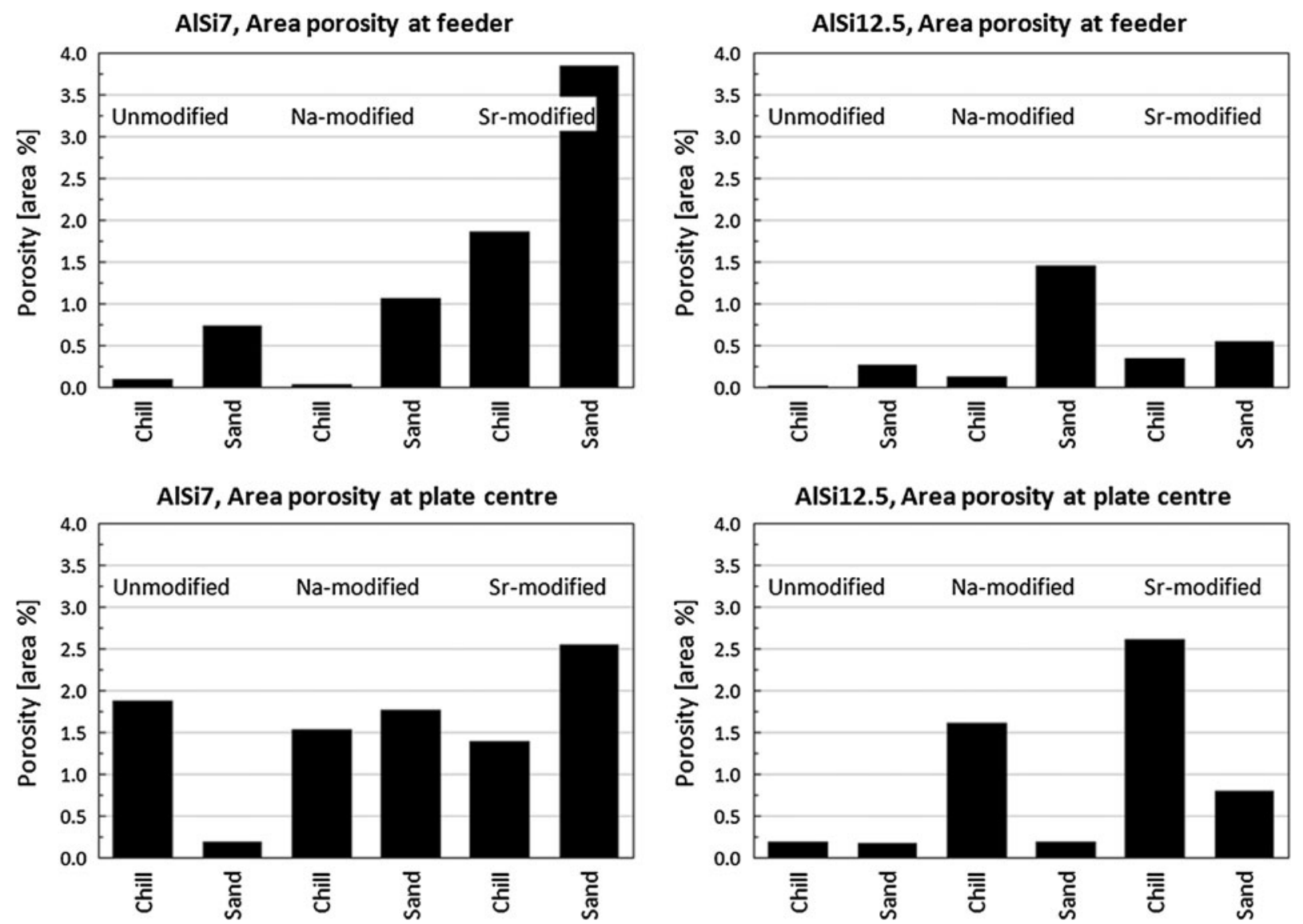

Fig. 13 - Percentage area of porosity measured in each sample. Top row is porosity near the feeder (position F, Fig. 2); bottom row is at the center of the plates (position C, Fig. 2). The left-hand graphs are for the Al-7 pct Si alloy and the right-hand graphs are for Al-12.5 pct Si alloy. 
approximately 10 times larger than in unmodified castings. In the Sr-modified castings, the eutectic cells nucleate on potent particles suspended in the melt ${ }^{[14]}$ and are largely spherical even near the chilled surfaces where conditions for columnar growth are ideal. This confirms previous theories that the eutectic cells form in the melt between dendrites and that there is no actual eutectic front growing from the surface towards the center of the casting. ${ }^{[6,15,22]}$ The effect is that Sr-modified castings are unable to form a solid shell but rather solidify in a mushy manner in which the space between the initial Al dendritic grains gradually fills with large eutectic cells.

These growth mode variants affect the porosity distribution within the casting. Unmodified castings have fine eutectic cells throughout the casting. Because they are densely packed near the surface, an effective solid shell is formed, particularly at higher cooling rates in the chill molds (Figures 7 and 9). Consequently, porosity tends to form towards the center of the casting, or at least inside the densely packed eutectic structure. The size of the pores between these fine cells is small.

Na-modified castings tend to form solid shells of columnar eutectic cells near the surface, particularly in the chill molds. These regions tend to be porosity free, and again, any porosity is more likely to be found towards the center of the casting. Porosity is more dispersed at slower cooling rates as the solid shell becomes less well defined as the eutectic cells become more equiaxed.

Figure 12 shows that the solid shell that forms in the chilled castings creates an open path from the feeder some distance into the casting so that the porosity level near the feeder (position $F$ ) is reduced. At the center of the plates (position $\mathrm{C}$ ), the chills also creates a solid shell, but this area is too far away from the feeder and large pores form at the center of the casting.

Figure 13 shows that a high level of porosity is found close to the feeder in the Na-modified sand-cast 12.5 pct $\mathrm{Si}$ alloy. This alloy is cooled slowly and the thermal gradient through the casting is small. The few primary dendrites that form at the surface in combination with the first eutectic grains create a thin solid shell. The heat from the adjacent feeder keeps the entire region hot so that it solidifies as a mush where eutectic cells can nucleate almost simultaneously throughout the remaining liquid. As the cells grow, they block the feeding path to the feeder, and because there is only a thin, weak solid shell, the surface collapses trapping pools of liquid between the eutectic cells; see also Figure 11(e). At the end of solidification, porosity forms in these liquid pools.

Away from the feeder, in position "C," the cooling power of the sand is sufficient to create a solid shell with a low level of porosity, thus causing the pores formed at the end of solidification to be evenly distributed over a large volume in the central region of the plate.

When Sr-modification is used, the cells grow in an equiaxed manner throughout the casting, and the amount of solid shell formed near the surface is small compared with the unmodified and Na-modified castings. This means that rather than being almost porosity free near the surface, porosity becomes dispersed throughout the casting. Thus, pores are evident on the boundaries between the eutectic cells.

Overall, the total porosity content of the Sr-modified alloys is the greatest, followed by the Na-modified alloys with the unmodified alloys generally having the lowest porosity content (Figure 13). Much previous work, ${ }^{[4,16,17,21]}$ although not all, ${ }^{[23,24]}$ has shown that addition of $\mathrm{Sr}$ leads to an increase in porosity, as in the current study. Whilst a significant reason for the changes in porosity may be due to how the microstructure affects feeding, it could also be related to the addition processes for $\mathrm{Na}$ and possibly of $\mathrm{Sr}$ as well.

When pure $\mathrm{Na}$ is plunged into the molten aluminum, there is a relatively violent reaction, and some of the molten $\mathrm{Na}$ floats on the surface of the melt. As a result, the elemental yield is only 25 to 50 pct, and the amount of porosity in the samples varies considerably. It is likely that in the process of adding $\mathrm{Na}$ to the melt, which has to be done after degassing, more gas (i.e., hydrogen) is introduced into the melt and that the amount depends on the vigor of the reaction and the ambient conditions.

The porosity content in the Sr-modified castings is higher than in the unmodified castings, even though the Sr master alloy was carefully added to the melt to avoid the introduction of further hydrogen gas. This suggests that the added $\mathrm{Sr}$ may increase the amount of gas rejected to the liquid during solidification, although no firm conclusions can be drawn on this point from the current investigation. Alternatively, the measured porosity levels may have a certain degree of inaccuracy inherent from the necessary elimination of fine-scale features through the image analysis process.

As well as the modifiers and the effect that they have on the eutectic structure, the amount of primary $\alpha-\mathrm{Al}$ is also important. The Al-7 pet Si alloy contains about 50 pet primary $\alpha$-Al compared with only a small amount in the Al-12.5 pet $\mathrm{Si}$ alloy, which is nominally fully eutectic. Even in sand castings, columnar dendrites several millimeters long grow from the surface towards the center of the casting until the transition to equiaxed grain formation occurs. This CET occurs when the local temperature gradient becomes sufficiently low. When this happens, conditions in the melt are such that the equiaxed dendritic grains may form almost simultaneously at any point in the melt. Later, eutectic cells form between the grains. It is in the remaining final liquid between these cells and grains that porosity typically forms. These results are similar to those from a study by Dinnis et al. ${ }^{[17]}$ using an Al-9 pet Si alloy.

In the 12.5 pct $\mathrm{Si}$ alloy, some dendrites are still able to form at the beginning of solidification even though the alloy is close to being fully eutectic. There appear to be more dendrites in the Na-modified alloy than in the other alloys possibly because the addition of $\mathrm{Na}$ tends to move the eutectic point towards higher Si levels. ${ }^{[25]}$ Since the eutectic forms early during solidification, it is easier to form a solid shell in these alloys, and consequently, the shell can become much thicker. The growth mode of the unmodified and Na-modified castings allows this shell to push porosity towards the center of the casting; see Figures 7(b) and (e) and Figures 9(b), (d), and (e). 
This is also the case in the Sr-modified 12.5 pct Si alloy chill castings where a distinct porosity-free zone, 3- to 4-mm thick is found (Figure 9(f)).

\section{B. Feeding}

A major way that the microstructure affects porosity formation is through its influence on the feeding of shrinkage. It is apparent from Figures 11 and 12 that feeding conditions change significantly as a function of melt treatment and alloy composition. In a plate with a feeder attached at one end, as in the current investigation, it is generally acknowledged that the feeder is active to a distance equal to 1 to 2 times the plate thickness from the feeder ${ }^{[19]}$ and that this can be extended with a tapered open feeding channel down the center of the casting. ${ }^{[19,26]}$ Since the feeder neck ends just above the top edge of the images shown in Figures 11 and 12, castings are expected to be relatively free of porosity in the area covered by the images. This is clearly not the case in the modified alloys.

In the sand-cast samples, shown in Figure 11, it can be seen that in the 7 pct Si alloy, porosity is trapped between dendrites. As previously described, the Namodified castings form a shell so that porosity begins to form approximately $2 \mathrm{~mm}$ from the surface whilst the Sr-modified castings contain porosity throughout the casting, even near the surface. In the chill-cast samples (Figure 12), it is clear that the increased cooling rate creates a stronger, thicker shell such that porosity is pushed towards the feeder. This helps to make the Namodified castings porosity free in this region, and it also reduces the total amount of porosity in the $12.5 \mathrm{pct} \mathrm{Si}$ alloy. However, this was not observed in the 7 pct $\mathrm{Si}$ alloy (Figure 13). The volumetric shrinkage during solidification in the eutectic alloy is less than in the hypoeutectic alloy ${ }^{[10]}$ and, as such, accounts to some degree for the difference in porosity level in the two alloys. However, it is still clear that the large fraction of primary dendrites in the 7 pct $\mathrm{Si}$ alloy increases the number of isolated pockets of liquid at the end of solidification and that these become sites for porosity. Furthermore, in the slow-cooled sand castings, there is a large volume of equiaxed $\alpha$-Al grains that reduces the feeder's ability to provide fresh melt to the solidifying volumes between the eutectic cells. In the Sr-modified sand castings and in the hypoeutectic chilled castings, the feeder has only a limited effect because the combination of less planar growth and larger eutectic grains (that nucleate and grow in the liquid detached from the solid shell) can block the feeding paths even in areas close to the feeder.

\section{A Combined Model for Porosity Formation in Al-Si Alloys}

Combining the results from the current work with previous studies, ${ }^{[8,13-17,21]}$ it is possible to describe solidification and porosity formation in hypoeutectic Al-Si alloys.

Figure 14 shows schematically the structure of various solidifying $\mathrm{Al}-\mathrm{Si}$ alloys at approximately $70 \mathrm{pct}$ fraction solid. It shows how dendritic grains (black) and eutectic cells (gray) interact at different Si contents and with varying types of modification to close off pools of liquid in which pores may form at the end of solidification. Dendrites grow in a moderate temperature gradient from the surface of the castings towards the center and clearly have an effect on restricting feeding. The CET is shown at the center of each figure, where the directional columnar dendrites are replaced by equiaxed dendrites with larger dendrite arm spacing. The eutectic cells in the unmodified alloy castings nucleate easily and in high quantity; hence, the cell size is small. Modified eutectics have larger eutectic cells. In the Na-modified alloy, the temperature gradient creates a layer of smaller cells near the surface. Below this refined zone, larger cells form that close off larger pools of liquid in which

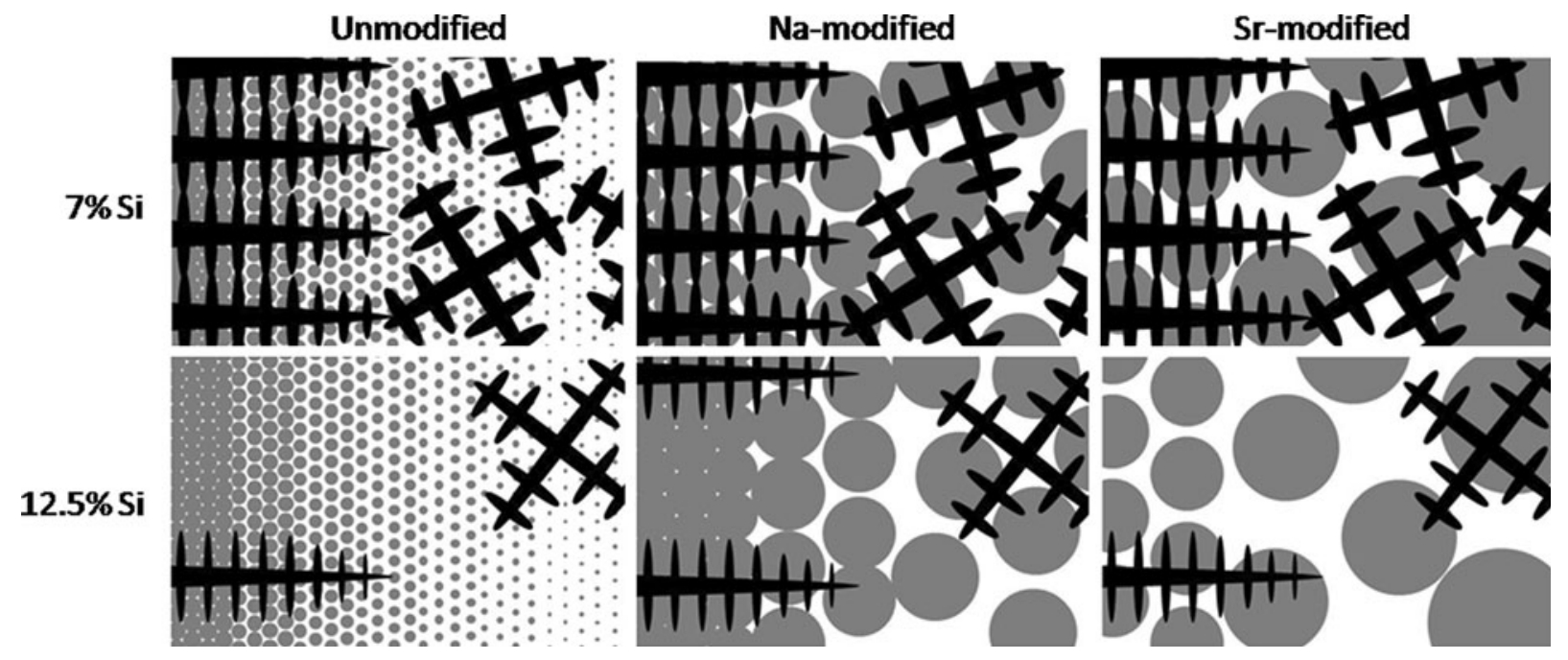

Fig. 14 - Schematic drawings showing the suggested structure of the various solidifying Al-Si alloys at approximately 70 pct fraction solid. The surface of the castings is to the left of each picture. The drawings show how dendrites and eutectic cells interact at different Si contents and with varying types of modification to close off pools of liquid in which pores may form at the end of solidification. 
porosity may form. In the Sr-modified alloy castings, the eutectic cells are larger still and do not form a solid shell at the surface. Hence, the final liquid pools become isolated in all parts of the casting, and therefore, the porosity is well distributed.

As the $\mathrm{Si}$ content increases towards the eutectic composition, the amount of primary dendritic grains is reduced, leaving more space between the grains for the increasing amount of eutectic formation. Since there is more space between the dendrites, the feeding path remains open for a longer time. At the same time, the temperature gradient makes it easier for $\mathrm{Na}$-modified alloys to form a planar eutectic front. In Sr-modified alloy castings, where a coherent eutectic does not exist until late in solidification, liquid becomes trapped between dendrites and growing eutectic cells. ${ }^{[15]}$ As a result, pores are formed in these isolated pockets of liquid. In Sr-modified castings, the eutectic cells (or agglomerates of eutectic cells and primary $\mathrm{Al}$ dendrites) are to some degree free to move in the melt (at low to medium overall fractions solid), and the liquid can flow between these so that it is possible to feed solidifying volumes even at relatively high fractions solid. The feeding mechanism active in these alloys is most likely a combination of liquid flow and movement of solid cells/ grains in the liquid (similar to the mass feeding mechanism described by Campbel1 ${ }^{[1]}$ ). As a result, porosity in Nr-modified alloys is also moved towards the center of the castings compared to alloys with lower Si contents.

\section{CONCLUSIONS}

The type of modification (i.e., none, $\mathrm{Na}$, or $\mathrm{Sr}$ ) strongly affects the nucleation and growth of eutectic cells. The fine cells in the unmodified alloy, particularly near the surface, tend to mean that porosity is located towards the center of the casting. The Na-modified castings also tend to have lower porosity levels with porosity moved towards the center of the casting.

In the large cell size Sr-modified alloys, which seem to solidify in a more mushy manner, porosity is distributed throughout the casting. Furthermore, it appears that feeders have limited effect on the coarse-cell Sr-modified castings.

The amount of $\mathrm{Si}$ is also important as $\alpha$ - $\mathrm{Al}$ can isolate regions of liquid that are subsequently difficult to feed. This means that the Al-7Si alloy castings typically have much more porosity than the near-eutectic Al-12.5Si alloys.

The latent heat evolved during the growth of primary dendrites will erase temperature gradients near the surface of the castings. This means that in Sr-modified castings, where nucleation of the eutectic cells is impaired by the modification, it becomes very difficult to create a solid shell of eutectic grains that grows from the surface of the casting towards the center.

Finally, the chill castings increase the size of the porosity-free layer near the surface for all modification types and increase the feeder efficiency by generating a more directional solidification pattern. It is apparent that the combination of modification type, the amount of $\alpha-\mathrm{Al}$, and the casting conditions are important to the production of sound castings.

\section{ACKNOWLEDGMENTS}

CAST Cooperative Research Centre (CAST CRC) is established under and is funded in part by the Australian Federal Government's Cooperative Research Centers Scheme. Niels Skat Tiedje gratefully acknowledges the support of CAST CRC during his period of research work at the University of Queensland. The project was also partly funded by the Danish Foundry Organisation, Otto Mønsted's Foundation, and Julie Damm's Foundation.

\section{REFERENCES}

1. J. Campbell: Castings, 2nd ed., Butterworth Heinemann, Oxford, U.K., 2003.

2. H. Fredriksson and U. Åkerlind: Materials Processing During Casting, Wiley, Chichester, U.K., 2006.

3. A.K. Dahle, P.A. Tøndel, C.J. Paradies, and L. Arnberg: Metall. Mater. Trans. A, 1996, vol. 27A, pp. 2305-13.

4. Q.T. Fang and D.A. Granger: AFS Trans., 1989, vol. 97, pp. 9891000 .

5. M.A. Easton and D.H. St. John: Int. J. Cast Met. Res., 2000, vol. $12(6)$, p. 393.

6. S.D. McDonald, A.K. Dahle, J.A. Taylor, and D.H. St. John: Metall. Mater. Trans. A, 2004, vol. 35A, pp. 1829-37.

7. M.O. Otte, W. Schneider, D.H. St. John, and J.A. Taylor: Giess. Forschung, 2001, vol. 53 (1), pp. 1-14.

8. A.K. Dahle, K. Nogita, S.D. McDonald, C. Dinnis, and L. Lu: Mater. Sci. Eng. A., 2005, vols. 413-414, pp. 243-48.

9. D. Argo and J. Gruzleski: AFS Trans., 1988, vol. 94, pp. 65-74.

10. H. Fredriksson and U. Åkerlind: Materials Processing During Casting, Wiley, Chichester, U.K., 2006.

11. A.K.P. Rao, K. Das, B.S. Murty, and M. Chakraborty: Mater. Lett., 2008, vol. 62 (12-13), pp. 2013-16.

12. M.O. Otte, W. Schneider, D.H. St. John, and J.A. Taylor: Giess. Forschung, 2004, vol. 53 (1), pp. 1-14.

13. Y.H. Cho, H.C. Lee, K.H. Oh, and A.K. Dahle: Metall. Mater. Trans. A, 2008, vol. 39A, pp. 2435-48.

14. M. Zarif, B. Mckay, and P. Schumacher: Metall. Mater. Trans. A, 2011, vol. 42A, pp. 1684-91.

15. R.H. Mathiesen, L. Arnberg, Y. Li, V. Meier, P.L. Schaffer, I. Snigireva, A. Snigirev, and A.K. Dahle: Metall. Mater. Trans. A, 2011, vol. 42A, pp. 170-80.

16. S.D. McDonald, K. Nogita, and A.K. Dahle: J. Alloys Compd., 2006, vol. 422 (1-2), pp. 184-91.

17. C.M. Dinnis, M.O. Otte, A.K. Dahle, and J.A. Taylor: Metall. Trans. A, 2004, vol. 35A, pp. 3531-41.

18. J. Campbell: Castings Practice, Elsevier Butterworth-Heinemann, Burlington, MA, 2004.

19. W.S. Pellini: American Foundryman, 1953, vol. 24 (6), pp. 62-71.

20. J.R. Davis (Ed.) Machining of Aluminium and Aluminium Alloys, ASM International, Materials Park, OH, 1989, pp. 761-804.

21. A.K. Dahle, J.A. Taylor, and D.A. Graham: Alum. Trans., 2000, vol. 3 (1), pp. 17-30.

22. C.M. Dinnis, A.K. Dahle, and J.A. Taylor: Mater. Sci. Eng. A, 2005, vol. 392 (1-2), pp. 440-48.

23. D. Emadi and J. Gruzleski: AFS Trans., 1994, vol. 102, pp. 30712.

24. J. Kim, H. Kwon, D. Kim, and C.R. Loper, Jr.: AFS Trans., 1997, vol. 105, pp. 825-31.

25. M.D. Hanna, S.Z. Lu, and A. Hellawell: Metall. Trans. A, 1984, vol. 15A, pp. 459-69.

26. G.K. Sigworth and C. Wang: Metall. Trans. B, 1993, vol. 24B, pp. 349-64. 